\title{
Restorative Justice and Sexual Assault: Outcome Appraisal Through Textual Analysis
}

\author{
Keith V. Bletzer ${ }^{1, *}$ and Mary P. Koss ${ }^{2}$ \\ ${ }^{1}$ School of Human Evolution and Social Change, Arizona State University, Box 87-2402, Tempe AZ 85287, USA \\ ${ }^{2}$ Mel and Enid Zuckerman College of Public Health, University of Arizona, PO Box 245209, Tucson AZ 85724, USA
}

\begin{abstract}
Restorative Justice is a community alternative to criminal justice. Its principles and practices are grounded in harm reduction, consensually-determined reparation, and in many applications, a facilitated conference between an offender and respective victim, and family members and/or community persons impacted by the crime. Projects based on Restorative Justice are rare for sex offenders. In this article, we review one such program funded as a demonstration project. Based on the rubric that we adapted from a template developed by Stephen Webster, we assessed the veracity of apology letters written by adult sex offenders, who earned the right to apologize to their victim, following participation in a 12-month program based on principles and practices of Restorative Justice. Content of the apology letters demonstrated anticipated changes in classic features of sexual assault as a harm-causing, ego-centered, trauma-producing, controlseeking, relationship-imposing act. Despite individualized formulation by each responsible person, the letters from misdemeanor and felony cases were similar in acknowledgment of harm and in the articulation of gratitude, but varied in responsibility acceptance and trauma discontinuation.
\end{abstract}

Keywords: Restorative Justice, textual analysis, felony and misdemeanor sexual assault, apology evaluation, violence against women, alternatives to criminal justice.

\section{INTRODUCTION}

Applications of Restorative Justice (RJ) to sexual assault are few in number, compared to use with cases of property damage, petty theft and juvenile delinquency. Before its application to sexual assault, RJ programs focused on societies where members accepted civic responsibilities [1,2], groups that embraced spirituality [3-5] and traditional communities whose problems were resolved by culturally-grounded interactions $[6,7]$. When RJ initially was proposed for violence against women, feminists had already been seeking an effective form of "alternative justice" $[8,9]$ that would fit communitarian concerns across multiple sectors and provide more attention to sexual assault victims [10]. An alternative model was needed that would eliminate potential retraumatization of the victim [5, pp. 28-31; 11, pp. 219-221; 12, pp. 20-21].

RJ for violence against women was first applied to domestic abuse in communities that encouraged non-violence and supported inter-personal respect $[13,14]$. In the early explorations sexual assault was subsumed with partner abuse with ongoing physical violence perpetrated by an 'intimate other' [8], rather than 'brief acquaintance' more commonly associated with sexual assault [15]. Over time RJ was sought by persons disillusioned with criminal justice $[16,17]$ and

*Address correspondence to this author at the School of Human Evolution and Social Change, Arizona State University, Box 87-2402, Tempe AZ 85287, USA; E-mail: keith.bletzer@asu.edu groups seeking autonomy from mainstream retributive practices [18, p. 94]. RJ is viewed as an alternative to criminal justice, even though notions of civic responsibility differ within and across societies. In this article we explore one application of RJ for sexual violence against women of varied socio-economic status in a medium-sized city of the southwestern United States. Desire for an alternative to criminal justice guided participants to choose to opt-in to the program.

\section{INTRODUCTION TO RESTORATIVE JUSTICE}

In Restorative Justice, as we use the concept, consideration is given to victim, perpetrator of the transgression, and community and/or social network to which each belongs. Thus, constituencies include survivor victims and offenders, and family and friend networks for each, and community members [14]. Several conferencing models embody RJ principles. "Sentencing circles," for example, evolved into circles of support and accountability to facilitate transition on release of high risk sex offenders from prison $[19,20]$. Similarly, "talking circles" developed into a multi-faceted model for issues other than sexual assault [9, 21]. Family conferencing began as a police-facilitated meeting with the offender and family without the victim in attendance; close kin of each later were included as essential to mediation [9, $22,23]$.

Facilitated conferencing for sexual assault comprises a face-to-face meeting of persons directly affected and includes, at minimum, culturally-responsive gestures to en- 
courage effective discussion and collaboration [24, p. 27], inclusive dialogue [25, p. 285], and confidentiality by those in attendance [24, pp. 103-115; 26, pp. 272-275]. Conferencing is broader than legal due process. Where procedures disproportionately emphasize the offender, the potential exists for re-traumatization, especially when a victim is brought into the process as a "witness" [27-30]. Court process focuses on two adversaries that meet during a trial with emphasis on witness and victim credibility, after evidence-gathering to adjudicate responsibility and assign offender retribution. "Credibility" is often found lacking by first responders at point of initial reporting, which derails potential cases from arrest and subsequent trial [31, 32].

Studies of facilitated conferencing have reported small but significant reductions in re-offending across a range of crimes for legal jurisdictions in Australia, Canada, New Zealand and the United States [25, 33-35]. Sexual assault cases in these programs are few or non-existent. Compared to domestic violence, "constant presence" by kinship or marriage is absent in sexual assault. Most sexual assaults take place between persons already minimally acquainted and/or those formerly in a relationship.

Versions of RJ that emphasize verbal apology have been criticized as inappropriate, as perpetrator regret is often considered cyclical [36, compare 37]. Thus, RJ has been perceived as a "soft option" to a serious crime [7, 27, 38], which ignores benefits of facilitated conferencing as a forum for survivor victims to tell their story [39] and share in a mutual decision-making on the reparation to be performed by the responsible person [40]. "Choice" and "voice" are foundations of RJ that correct power imbalance [9]. During the early dialogue, for example, those responding to the critics suggested that conclusions preceded the research on adult sexual assault programs [2]. Involving survivor victims, RJ focuses on that which research identifies as the most difficult for sex offenders, which is recognizing the harm caused to a specific person in contrast to greater acceptance of responsibility by offenders in other crimes [41-43].

\section{ADAPTING GLOBAL PRINCIPLES TO A LOCAL PROGRAM}

Funded as a demonstration project, the RJ program we reviewed was one of the few created for adult sexual assault cases. The program began as a community-university partnership [44] that centered on facilitated conferencing for mutual determination of reparation by both the survivor victim and responsible person [45]. Consensual determination replicated a deterrence approach that has been theorized to decrease repeat offenses $[46,47]$. Modifications to the program were made in its early stages, before it was moved to the university. Funding was limited primarily to program administration. Owing to local concerns that program records could be subpoenaed, if a participant were to be readjudicated for trial, psychometric measurements and other forms of detailed evaluation of responsible persons and survivor victims were not possible. Collection of evaluation data was aimed at participant satisfaction, adherence to program requirements, and the reasons for choosing "to opt-in," and monitoring data to examine fidelity to the core elements of the adapted RJ model (analysis in progress). For a review of program objectives, see [48]; for its theoretical founda- tions, see $[28,49]$; for an earlier review of the program, see [50, pp. 305-306].

A carefully planned conference followed recruitment and consent. Survivor victim and offender, and family and friends of each, were instructed on the procedures and expectations of conferencing, which offset potential sabotage of the process. Fifteen professionals with previous experience in sexual crimes were chosen as facilitators and observers (11 women, four men). Each received training in facilitated conferencing. To increase survivor victim comfort, seating around a table obscured the lower body. Each participant with respective supporters entered the room separately. The conference was held at one end of the university's public safety facility, separated from student traffic; none of the conferences ever required intervention by security.

Drawing on available materials from responsible persons who completed the 12-month program, we conducted a textual analysis of letters of apology, based on an adapted template for assessing sexual assault developed by Stephen Webster [51]. Because the letters were the end-point in the reparative process, we examined to what extent participation in a program grounded in $\mathrm{RJ}$ principles modified attitudes on sexual assault as a harmful act that seeks control over a victim, generates an ego-centered and empathetically inappropriate relationship, and ultimately denies victim autonomy. Theoretical basis for expected change is derived from models of self-efficacy proposed by Albert Bandura $[52,53]$ and revised by others, who posited the capacity to take ownership of corrective actions in matters that affect self, and others. Thus, we assume the overall effectiveness of RJ can be ascertained by content review of apology letters prepared to be read by and/or heard by a respective survivor victim (see Methods). Conferencing began a 12-month process to reverse the disadvantage of harm through assault, and mutually determining the reparation equalized the offender's uneven power. Conference-selected reparative activities were community services that typically relied on time and skills of various kinds. These activities did not interfere with employment of responsible persons, but they did require judicious planning of time and program commitment.

All cases were adults who had been charged with felony sexual assault and misdemeanor statutory indecency, such as public exposure. Because all but one responsible person were male and most the survivor victims were female, we use gendered pronouns for participants.

\section{METHODS}

We utilized a qualitative approach that emphasizes data points ("benchmarks") comprising the Letter of Clarification and Responsibility required from responsible persons at the exit meeting with the volunteer community board; conferencing checklist; police reports and intake statements and ongoing case notes. In this analysis we focus on the apology letters. To assess the letters we used a rubric that we adapted from the "template" developed by Stephen Webster [51] with incarcerated offenders, who wrote hypothetical letters to their victims, before they received an intervention. Letters he had analyzed by forensic psychologists were never sent to "real victims." In contrast, each responsible person letter written for the program we reviewed was sent to the 

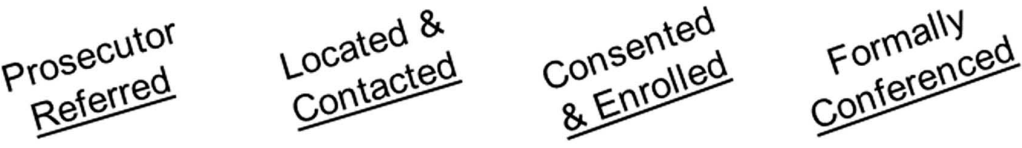

43 FSV, 1 MSV

\section{Felony Cases}

$n=42$

$n=24$

\section{Misdemeanor Cases}

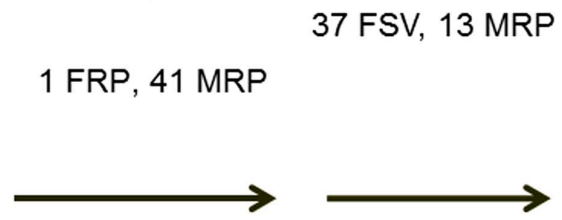

26 FSV, 11 MRP
$23 \mathrm{FSV}, 7 \mathrm{MSV}$

20 FSV, 11 MRP

$1 \mathrm{FRP}, 26 \mathrm{MRP}$

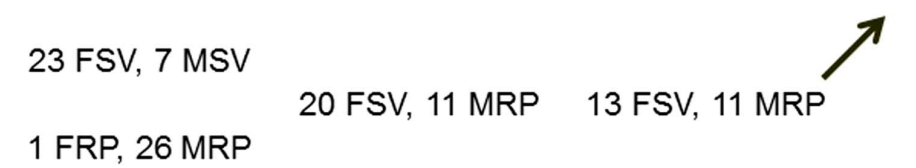

(9)
$\mathrm{N}=20$

Fig. (1). Case Types $>\mathrm{SV}=$ survivor victim, $\mathrm{RP}=$ responsible person; $\mathrm{F}=$ female and $\mathrm{M}=$ male.

respective survivor victim; a few were heard, when a survivor victim attended the exit meeting. Letters were the endpoint in a process of intra-personal change. Textual analysis of the letters served as a summative evaluation of overall effectiveness of program participation that included reparative activities mutually-determined by the survivor victim and responsible person through facilitated conferencing, psychotherapy for responsible persons, periodic review by a community board, scheduled payments for therapy (paid by responsible person for both, if also required by survivor victim), and regular consultation with program staff.

Participants: Potential clients were referred by city and county prosecutors from a large pool of felony and misdemeanor investigations (February 2003 to August 2007). Thirty percent of the referred cases were consented and conferenced, and $80 \%$ of these responsible persons eventually completed the program, which ended August 2008, twelve months after the last referral. Attrition is common in assault cases. Numbers are greater at the point of initial reports to the police when compared to cases of sexual assault actually prosecuted and convicted by the courts $[17,27,38,50,54$, 55]. Similarly, a very small percentage of the forensicphotographic materials, prepared beforehand, are actually used as evidence in court [56].

In the program we reviewed, staff contacted and offered an opportunity to each referred victim "to opt-in" and participate in the twelve-month program. For felony assault cases, this resulted in a voluntary pre-charge diversion (roughly half the referrals were for acquaintance rape) or choice to a post-charge action for misdemeanor sex crimes (e.g., indecent exposure).

Sixty-six referrals were received over 2.5 years of program operations. All responsible persons were first-time offenders. Among 66 referrals, the primary survivor victim was a man in 42 cases and a woman in 24 cases. Of 26 referred cases of indecent exposure, for example, eight involved male security guards who had witnessed parking lot incidents on a surveillance camera. Male guards gave their permission to proceed and supported the program, but none participated in meetings. Of the few misdemeanor cases in- volving targeted women, very few female survivor victims prepared an impact statement. Following criteria for participation exclusion, no referred case involved domestic abuse, persons married to each other, or an underage juvenile or minor.

Not everyone referred was enrolled. Staff made a concerted effort to locate each survivor victim, explain options, and secure consent, before they contacted the corresponding responsible person. More responsible persons were not found than survivor victims (14/5) and more survivor victims declined than responsible persons (23/2). To avert coercion each offender was contacted after their respective victim consented. Of 66 referrals presented the option to enroll, consent rate was $70 \%$ for felony and $65 \%$ for misdemeanors. All together 22 paired individuals "opted-in" as cases. All the responsible persons (offenders) consented and enrolled were men and all survivor victims in felony cases were female; $45 \%$ of the victims in misdemeanor sex crimes were men, typically security guards. Twenty of the 22 consented cases resulted in a conference (Fig. 1).

No conference was held for two felony cases; one offender withdrew and one survivor victim wanted more than the responsible person could provide. All responsible persons attended their conference. Felony survivor victims attended more often $(78 \%)$ than those consented in the misdemeanor cases $(18 \%)$. Sixteen of the 20 conferenced cases completed the 12-month program (three felony responsible persons later withdrew and one responsible person was rearrested for a misdemeanor). Completion was $66 \%$ for felonies $(n=6)$ versus $91 \%$ for misdemeanors $(n=10)$.

Responsible persons were usually Anglo men with few material resources. Most were divorced, separated or never married (55\%) rather than married $(45 \%)$. Income ranged from more than one-half below $\$ 24,999$ (57\%) to one-third greater than $\$ 50,000(31 \%)$. Many were unemployed (45\%); some worked full-time $(35 \%)$ or part-time $(20 \%)$. One-third of the felony crimes involved "strangers" with no prior contact; a few had current or past romantic ties. All the misdemeanor crimes involved persons who were strangers. A1though mean age varied, the range was similar $(M=26$ years 
for felony, range 19 to 67 years; $M=42$ years for misdemeanor; range 19 to 66 years). Police reports identified use of alcohol and/or drugs before the assault by fewer responsible persons in misdemeanor (17\%) than felony cases (73\%). Survivor victim alcohol use in contrast was limited to felony cases, usually for college students. Several responsible persons were living with a mild disability (14\%) including one responsible person who was re-arrested and withdrawn from the program. Accommodations were met, such as an interpreter for a victim and corresponding offender who were deaf. Compared to local demographics, program referrals over-represented African Americans, under-represented Hispanics. No enrolled participant was Native American or Asian American. Ethnicity was unlisted in $34 \%$ of the 66 referrals.

Cases referred by local prosecutors constituted the target population, and sampled cases were consented persons who participated in a conference and completed the program. Variation between target population and sampled respondents adheres to the expectation of 'synecdoche' or part-towhole, common for most studies in the social sciences [57, pp. 70-76]. In this analysis, we include all available letters, or more than half the sampled cases. Concern for the possibility of subpoenaed records restricted data collection; psychometric interviews were not permitted and the case notes from offender psychotherapy were "privileged." Thus, our analysis is closer to a retrospective case-comparison. Having a sample of male offenders who completed the program, we sought to ascertain to what extent participation generated "changes" in the indicators [58] that serve as typical characteristics of sexual assault. We assumed that qualitative changes would be evident in letters of apology, when compared to the pre-participation statements in police records and intake forms, which represent a point in time immediately before beginning the program.

Materials: All responsible persons who completed the program generated Letters of Clarification and ReIntegration ("apologies"). The apology letter was meant to be read at the "exit" meeting with the community board, where the responsible person accepted full responsibility, apologized to the survivor victim and described aspects of personal growth. Impact Statements were read at the conference, as a statement of how the assault had affected the survivor victim; most were prepared by the survivor victim, some by surrogate victims who "stood-in" for the real victim [for comparison of impact statements and apology letters, see 59]. Twelve months separated the exit-meeting apology letters and impact statements that began the RJ process. Neither document occurred spontaneously as speech; each was prepared beforehand "to be read" by one participant "to be heard" by the other. Physical presence was required by each responsible person at their respective exit meeting and encouraged for survivor victims. Pre-delivery writing is theorized to have benefits for the author, and recipient, when its communication has a purpose $[60,61]$. Thus, the act of writing by each participant was not likely to interfere with program benefits that were being experienced by responsible persons.

At the request of some responsible persons, apology letters were not retained in program files. Nonetheless, the final letter from each responsible person was sent or personally delivered by staff to his survivor victim. Of sixteen responsible persons completing the program, letters of apology reached 16 intended recipients. Of the 16, six were not available in any form. Ten letters were available for textual analysis (6 misdemeanors, 4 felonies). Retention of letters was $62.5 \%$ of persons who completed the program. For ten available letters, eight were a page or less; one was two pages, one was four. To augment textual analysis we drew on program files and police reports to compare the offender's preprogram statements with their apology letters.

Analysis: We utilized three strategies. First, we used sequential case development or 'extended case method' [62, 63] to appraise apology letters. This technique considers a phenomenon by highlighting its characteristics, before identifying 'themes' for coding [64] as 'units of analysis' [65, pp. 67-83]. In our exploration of language by responsible persons after twelve months of reparation we emphasize "meaning" and "context" [58] of the written apology letters. Second, we adapted Webster's assessment [51] developed from hypothetical apologies written by sex offenders. Webster recruited men from the Prison Service Sex Offender Program in England (half were rapists of adult victims and half were adult molesters of children) and had them write an apology to respective victims (never sent) before receiving an intervention "to undermine belief that abuse was harmless or positive for the victim" [51, pp. 283-284]. Third, we reviewed data from an observation checklist used at the twenty facilitated conferences.

We converted Webster's scoring template into ten 'domains' [65, pp. 70-75] to replicate the indicator factors [58] that he originally proposed. To rate the hypothetical letters from his sex offender sample, Webster recruited four forensic psychologists, who used 16 categories derived earlier in his co-authored study of child sex offenders from a residential unit [66]. Over two phases, he reduced 16 categories to ten (first), then to seven (second), resulting in an "inter-rater reliability" of .764 from the half that were rapists [51, pp. 288-291]. Webster proposed that the derived scores were correlated with observed "clinical change" in empathy without providing data specific to the changes. His efforts were framed by quantitative expectations, whereas we emphasize a qualitative analysis of text from letters. We used Webster's final seven dimensions for the sampled adult offenders. To derive the full ten dimensions, we separated 'Control' into two categories and added one (see below). Adapting Webster's original template to review the apology letters is grounded in horizontal modeling, rather than "vertical modeling," where the main patterns emerge through similarity, omission, congruence and sequence [65, pp. 95-112].

Our scoring scale expands analysis beyond "empathy," as claimed by Webster, and captures classic features of sexual assault as a harm-causing, trauma-producing, relationshipimposing, ego-centered, control-seeking act. Thus, we view the apology letter as an inter-related series of dimensions that replace those of sexual assault [67]. Six of the ten constructs emphasize demonstration of growth and a change in attitude: (a) Willing-to-Learn by owning the need to increase self-efficacy; (b) Acceptance-of-Responsibility by taking full responsibility without externalizing reasons for one's actions, making excuses or displacing blame onto the survivor victim; (c) Harm-Acknowledgment that demonstrates recog- 
nition of harm caused by misguided choices. Two of the five dimensions minimize reference to the incident: (d) created by splitting "Control," Space-for-Survivor-VictimAutonomy shows how a responsible person can cultivate space for survivor victim growth and healing without further harm; (e) Trauma-Discontinuation softens mention of the offense through brevity and avoids re-abuse by not using trauma-inducing reminders of time and/or place in relation to the incident. For each dimension the more carefully the responsible person could articulate language that referred to his inappropriate action (sexual assault), the higher the score. We added (f) Gratitude Articulation, when the responsible person thanked the RJ program, staff, family, volunteer board and/or the local community.

Four remaining dimensions required the responsible person to minimize and/or not refer to the incident: (g) Egocentric Neutralization was evident when the responsible person refrained from self-celebratory statements or those flaunting self-importance; (h) Control Avoidance was having no comments that suggested how the survivor victim should feel, think or act, from the present moment forward; (i) Relationship Extinction resulted through omission of reference to any aspect of the incident and/or later trauma that linked himself to the victim, thus divesting a reason to be a part of the survivor victim's life; (j) Self-Suffering Effacement avoided reference to hardships the responsible person endured or difficulties he might have experienced during his participation. Omissions are significant as a dimension of intra-personal growth and parallel use of 'analytic induction' [65, pp. 75-81] through a disengagement with the survivor victim and reflexive awareness of the harm that was caused.

The score sheet we developed was similar to an educator's rubric for assessment, or the guidelines used by judges to award points in competitive performance. In the field of education it is said that a rubric provides a view "inside the teacher's mind" that guides the student in how to prepare assignments [68, p. 62]. In our analysis in contrast, the evaluative appraisal of apology letters provided a focused view of salient points generated by each responsible person following learning and self-reflection through program participation. No one was told "what to write." The apology letter was meant to demonstrate responsible personal growth, when read to the survivor victim, and the appraisal by textual analysis was the means to ascertain to what extent change through program participation actually had taken place.

For the ten-item rubric, potential scores ranged from 0 (minimal) to 1.0 (high). Elements in the letter that effectively met expectations received high scores. High scores were based on an expression of language that clearly fit a category $(\mathrm{a}, \mathrm{b}, \mathrm{c}, \mathrm{d}, \mathrm{e}, \mathrm{f})$. Four other categories scored high when negative comments were absent $(g, h, i, j)$ and "left unsaid" [69]. Any inappropriate reference to the perpetrated assault does not reflect growth. Reflective participation was expected to improve exit-meeting expressions of sincerity in the letters with judicious textual omission.

Similar phrases occasionally received different scores [70] across apology letters, given variation in word choices and how well statements communicated holistic tone of growth. That is, phrases in one instance could blend with surrounding context, but the same phrase might clash in another letter's textual setting and sound "harsh." At times, the order of presentation was considered in scoring, for example, when a responsible person rushed an apology or continued to other matters, after having apologized, and/or acknowledged harm he caused. Transformation of the textual statements into quantitative scores upholds confidentiality and avoids the dilemma of personal data "too sensitive" to be used [71].

We scored each category for all letters before moving to the next one to avoid bias from 'halo-effects' (letter starts good, thereafter is perceived positively) and 'horn-effects' (letter starts poorly, thereafter is viewed negatively). For the first pass, we identified language that merited a 1.0, when a responsible person fully met expectations of the scoring guide, and 0.5 if they were "halfway" met. We re-visited letters to assign scores between 1.0 and 0.5 , and 0.5 and 0.0 points.

\section{EXTENDED CASE ELABORATION}

In the RJ program that we reviewed apology was an expected end-point in the reparative process, by which each responsible person earned the right to make amends for harm he caused. Although responsible persons were not required to apologize at the facilitated conference, an apology was noted in fifteen of 20 consented cases. Using a checklist, an observer identified what took place, such as description of the incident (each participant) and impact (supporters), input from both as to agreement on reparation plan. They rated verbal apologies as "spontaneous" $(n=7)$, "genuine" $(n=6)$, combined $(n=1)$ or spoken privately $(n=1)$. Conference preparations also were "checked" such as seating labels at the table, three timed breaks, and Do-Not-Disturb signs on the doors.

In an everyday apology, a person can acknowledge a transgression in etiquette [72], upgrade level of breach [73], alter an apology's intent [74] and intensity [75], universalize the expression of apology [76] and/or extend an "offer of forbearance" not to repeat [77]. In extreme forms such as sexual assault, harm affecting the victim is prolonged [46, 78] and forgiveness can shift the way that a victim feels and/or behaves toward an offender [79, 80]. Because it was not well-established in the literature on assault and violence $[79,81,82$; compare 83] 'forgiveness' was excluded as an observation exemplar in the conferencing checklist. One woman, however, among the 15 annotated verbal apologies, was observed "to forgive" the responsible person at her facilitated conference.

For ten cases with an available apology letter we include pre-program statements to give a view of the case context, before an offender began "learning" to become a responsible person, followed by a short excerpt from the apology letter. Police reports typically came from municipal or county jurisdictions, supplemented by university public safety for some felony cases. Variant in length from a few lines to several pages (two extremes noted below), they more often included a verbatim statement from the victim than the offender, although some were derived from notes of a separate taped sessions.

\section{Case-SA01: Sexual Assault of a College Sorority Member by a Former Boyfriend's Roommate}

Police Report: "He admits he took advantage of her..." Intake: "Two of us passed out on my bed... I awoke and 
began to fool around with her... Around noon she woke up... and seemed bothered by the fact we had slept together..." Apology: "I am not glad that I hurt (name)... Initially, I never felt like I did anything wrong... I never wanted to hurt you, but I did, and for that I am so very sorry...."

Case-SA02: Sexual Assault of Female Friend by Male Companion after Heavy Drinking at a Bar

Police Report: "Miss (name) said she never gave consent for sexual conduct with (offender) and she told him 'No' several times." Intake: "I took advantage of her and I don't know how to make things better..." Case Notes: "I explained to him how what he did constitutes a sexual assault, showing him the statute; he stated he did not know this was against the law." Apology: "I can't express how sorry I am for the pain I caused you... I don't expect you to forgive me...."

\section{Case-SA03: Woman Improperly Treated by a Massage Therapist in Chronic Disease Support Group}

Seven-page Police Report has statements from multiple victims, one statement from the offender, who tells the husband of one victim, "Your wife... was beautiful lying on the table..." Letter to Board: "One year ago I committed a serious crime of sexual misconduct for which I have taken full responsibility... (At some board meetings) I deeply regret and apologize for my offensive remarks... I want to atone for them...." Apology: "I now carry the memory that I have deeply harmed you...."

\section{Case-SA04: Sexual Assault of a Female Student after a Fraternity Party, by her date's Housemate}

Police Report describes several instances of penile insertion into vagina and mouth, holding the back of the victim's head... Later he "looked at her and said, "That was the worst sex I have ever had' before she left...." Intake: "I touched her while she was asleep... I grabbed a condom and raped her on the floor... She asked where her clothes were. I pointed to a pile in the corner...." Apology: "No matter how many times I say the words 'I am sorry' nothing will change the hurt that I have inflicted on you... I wish I had the power to turn back the hands of time...."

\section{Case-IE05: Indecent Exposure Involving Two Moving Vehicles on a City Road (Male Victim Target)}

Police Report provides no statement from the offender. Intake: "I was driving... In the lane next to me was one other car. I began to masturbate and the person in the car saw me..." Apology: "I disgraced myself by committing a sexual offense against an undeserving stranger... Though I can't take back what I did, I can move forward...."

\section{Case-IE06: Indecent Exposure by a Man Who "Stalked"} a Female Hiker in a Local Wilderness Park

Police Report describes apprehension of the offender without verbal statements. Intake: "I was in the area that was a well-known nudist area... I asked her if she was going to take her clothes off and go skinny-dipping... I could tell she was very upset by what I said...." Apology: "I have taken responsibility for what I did... It was not my intent to scare her or hurt her...."
Case-IE07: Indecent Exposure by a Non-Student Adult of Female Student in a College Library

Police Report: "I didn't mean for anybody to see me...." Intake: "I went to the Library and exposed myself to two persons... I believe it was a poor way of relieving stress...." Apology: "I am very sorry that I negatively affected years of hard work on her part with my selfish and thoughtless act..."

\section{Case-IE08: Lewd Behavior by Man in a Vehicle Caught on Camera in a Business Parking Lot}

Police Report in third person lists "details" provided by offender. Intake: "I parked my vehicle... I lowered my pants and started to masturbate... I feel ashamed for what I did...." Apology (no mention of parked vehicle): "I compromised my reputation and my family with my inappropriate behavior... It is very hard to accept I committed this offense...."

\section{Case-IE09: Indecent Exposure by man who Entered a Store and Targeted a Female Shoe Clerk}

Police Report provides no verbal statement from the offender. Intake: "While buying a pair of boots, I decided to expose my penis to you... My zipper was not broken and I exposed my penis on purpose to see what you would do...", Apology: "As much as I wish that I had not done what I did to you, I have accepted $100 \%$ responsibility... I understand that saying 'sorry' can only go so far... Nothing you did had any effect on the choices I made... I never meant to hurt you or frighten you. I am deeply and regretfully sorry for what I did."

\section{Case-IE10: Lewd Behavior by Man in a Vehicle Caught on Camera in a Business Parking Lot}

Eight-line Police Report contains no verbal statement from the offender. Intake: "In the parking lot I had a sexual impulse and I masturbated in my car... I didn't offend anyone other than the security guard... I've thought I was fortunate that I didn't offend any children...." Apology: "I never intended to harm anyone... I apologize to Mister (name)... He was only 19 at the time...."

For space considerations we limit excerpts from our textual analysis to four letters, as randomly selected cases (two of each type) to show how we scored apology letters according to responsible person growth. Randomization avoids an implicit "modal bias" when a researcher selects cases. Quotation marks identify verbatim statements and ellipses (...) indicate omitted phrases. We provide excerpts that illustrate adapted dimensions, abbreviate-italicize them in order of appearance within each letter, and summarize the scoring.

Case-SA01: Sexual assault of college sorority member by a former boyfriend's roommate. After heavy drinking at a fraternity party with a former boyfriend, they returned to his apartment; she fell asleep in his room. While she was unconscious, the responsible person (roommate) says he "took advantage" of her. In the morning, she called her roommate for a ride home. Initially she was concerned his fraternity brothers would make it "difficult" if she went to the police, so she hesitated. Two days later she reported the incident to police. After referral to the program and preparation by staff, she came to the conference with her parents. When the re- 
sponsible person accompanied his fraternity in a "sing-out" [serenade] at her sorority house, he was counseled on choices: "It didn't matter whether he knew she was not present, he should not have gone." When he was unable to complete psychotherapy due to cost, the community board accepted support group participation as an alternative. He became active in a campus rape prevention campaign and his fraternity designated a slide presentation he created as mandatory for new pledges. His apology letter was read fortyeight weeks after spontaneous apology at the conference, rated as genuine. Overall mean score on the adapted rubric was .82 .

Relationship (1.00): “This program... has allowed me to bring closure for myself and hopefully to [victim] and her family." Autonomy (.75): "Everyone in this room is aware of this incident in vivid detail." Trauma (.75): "I am not here to refresh your memory" [no re-abuse]. Learning (1.00): "[I had] a relationship with someone [victim] who challenged me, improved me, and made me strive to be better... This happened so I could realize what is truly important in life." Self-Suffering (.35): After we broke-up [post-incident] I became unhappy, angry, and full of contempt that I started drinking... I was forced to quit school, go home, and reevaluate my life... I became very depressed... I couldn't sleep, eat, go out or go to school." Gratitude (1.00): "I express gratitude to [coordinator], the program, board members and [survivor victim]... I have [victim] and the program to thank..." Harm (1.00): "I hurt [victim]... What I did was hurt someone whom I cared for and trusted, and even loved." Responsibility (1.00): "I never wanted to hurt you, but I did." Control (.85): "I hope the experience has been as beneficial for you as it has been for me."

For most the letter until the conclusion, the responsible person's active voice "I" was the subject causing harm. $\mathrm{He}$ avoided control-seeking by not wishing-desiring-wanting the survivor victim to think, feel, act in any way, or continue actions already in progress. Because his experience reappears throughout the letter (e.g., "consumed me"), EgoNeutralization was scored at .50.

Case-SA4: Sexual assault of female student after a fraternity party, where she fell asleep in her date's apartment. Housemate as responsible person wrote: "I came home... changed clothes and touched her while she was asleep. I asked for oral sex, she briefly engaged. I grabbed a condom and raped her on the floor..." He matter-of-factly minimizes her resistance: "She pushed me off two minutes later. Sex ceased." Police report states that she pushed him with both hands, "she continuously told him to get off... approximately five times." According to the coordinator, the victim said the responsible person was "defiant" at the beginning of the conference. Initially, his mother and father were "antagonistic toward the program, especially the consent form. They did not want their son to be called 'responsible person'... They brought an attorney to the conference and meetings ... Nine months later... Mother feels her son learned about taking responsibility... bringing them closer together as a family." Apology letter was scored overall at.71:

Harm (1.00): "No matter how many times I say 'I'm sorry' nothing will change the hurt I inflicted on you... My rash and impudent decision to sexually assault you has caused consequences I never dreamed of and changed our lives forever." Trauma (.15): "Because of my assault, you have many bad memories from the second semester of your freshman year... You'll carry these horrible memories the rest of your life... look past this horrible incident... to forget the endless pain that I have caused you and your family..." owing to harsh words referring to the trauma and its time frame. Autonomy (1.00): "I wish I had the power to turn back the hands of time; one rash and imprudent decision can forever alter a person's life." Responsibility (1.00): "I am truly sorry for the unnecessary pain I caused you, your family and friends. This letter in no way, shape or form excuses my behavior." Control (.50): "I hope you can move on... You have a long and prosperous life to live. Please do not allow my mistake to stop you from achieving your dreams. My wish is you will take my apology with sincerity..." Relationship (.25) [overlapped with Control extended through the letter]: "I hope in time this letter will mean something."

Other variables scored high for absence of self-reference, Ego-Neutralization (1.00) and Self-Suffering (1.00); Learning (.85) moderately high, and Gratitude (.50) low with no mention of thankfulness.

Case-IE5: Indecent exposure in the only case of a targeted male survivor victim involved two moving vehicles on a city road. Repossessing a policeman's car with his company's tow truck, he believed it was "the cop that came tearing after him." Instead, it was the responsible person who exposed himself in his moving vehicle. One conference observer commented: "victim was afraid of responsible person..." For this reason, he avoided the conference. The coordinator said the responsible person was "Very, very nice guy, full of shame... extremely compliant in every way..." Because his action implied he was attracted to men, the responsible person's wife in lieu of the absent victim recommended for reparation that her husband assist a gay-lesbianbisexual program, which he completed. He and she have two daughters. Coordinator: "He said that the conference was difficult for him... His wife said she felt she got to say what she wanted to say," which re-affirmed commitment to their marriage. Apology letter was scored overall at.85:

Trauma (.85): "In March ... A year ago [date/time]..." Responsibility (.75): "I disgraced myself by a sexual offense against an undeserving stranger... I was experiencing a great deal of pressure with low self-esteem, causing me to disregard my entire value system... I am deeply sorry." Harm (.85): "I am deeply sorry for fear, uncertainty and inconvenience this incident caused... and serious impact my actions have on everyone around me... I was not thinking how my actions impact others... I hope that you, my wife and my family accept my sincere apology." Gratitude (.75): "I am grateful for opportunity to participate in [program]." Learning (1.00): "I can move forward in hope of continuing to rebuild trust from my family, community and you... I reflected on the serious impact... I've learned a great deal about accepting myself." Autonomy (.65): "I can't take back what I did," and Control (.85) and Relationship (.85), given no statement of wishes to the survivor victim.

Other variables scored high for absence of self-referring language: Ego-Neutralization (1.00) and Suffering (1.00).

Case-IE9: As one of two male-female indecent exposure cases, the responsible person targeted a clerk in a shoe store. 
Table 1. Mean Scores for Ten Dimensions of Apology, by Type of Offense for Ten Cases

\begin{tabular}{|c|c|c|c|c|c|c|c|c|c|c|c|c|c|}
\hline & SA01 & SA02 & SA03 & SA04 & IE05 & IE06 & LA07 & LA08 & IE09 & LA10 & FSA & MIE & Sample Mean \\
\hline \multicolumn{14}{|c|}{ Apology Dimension } \\
\hline $\begin{array}{c}\text { Harm } \\
\text { Acknowledgment }\end{array}$ & 1.00 & 1.00 & 0.75 & 1.00 & 0.85 & 1.00 & 1.00 & 0.75 & 1.00 & 0.75 & 0.94 & 0.89 & 0.91 \\
\hline Ego Neutralization & 0.50 & 1.00 & 0.85 & 1.00 & 1.00 & 0.85 & 1.00 & 0.65 & 0.75 & 1.00 & 0.84 & 0.88 & 0.86 \\
\hline Control Avoidance & 0.85 & 0.85 & 0.65 & 0.50 & 1.00 & 0.85 & 1.00 & 1.00 & 0.75 & 1.00 & 0.71 & 0.93 & 0.85 \\
\hline $\begin{array}{l}\text { Willing to Learn } \\
\text { and Change }\end{array}$ & 1.00 & 0.65 & 1.00 & 0.85 & 1.00 & 0.85 & 0.85 & 0.85 & 0.75 & 0.25 & 0.88 & 0.76 & 0.81 \\
\hline $\begin{array}{c}\text { Gratitude } \\
\text { Articulation }\end{array}$ & 1.00 & 0.65 & 1.00 & 0.50 & 0.75 & 1.00 & 0.75 & 1.00 & 0.50 & 1.00 & 0.79 & 0.83 & 0.82 \\
\hline $\begin{array}{l}\text { Relationship } \\
\text { Extinction }\end{array}$ & 1.00 & 0.35 & 0.75 & 0.25 & 0.85 & 1.00 & 1.00 & 0.75 & 0.65 & 1.00 & 0.59 & 0.88 & 0.76 \\
\hline $\begin{array}{l}\text { Space for } \\
\text { Autonomy }\end{array}$ & 0.75 & 1.00 & 0.85 & 1.00 & 0.65 & 0.75 & 0.65 & 0.75 & 0.85 & 0.35 & 0.90 & 0.67 & 0.76 \\
\hline $\begin{array}{l}\text { Responsibility } \\
\text { Acceptance }\end{array}$ & 1.00 & 1.00 & 0.85 & 0.85 & 0.75 & 0.65 & 0.35 & 0.35 & 1.00 & 0.50 & 0.93 & 0.60 & 0.73 \\
\hline $\begin{array}{c}\text { Trauma } \\
\text { Discontinuation }\end{array}$ & 0.75 & 0.85 & 0.35 & 0.15 & 0.85 & 0.65 & 0.75 & 1.00 & 0.85 & 1.00 & 0.53 & 0.85 & 0.72 \\
\hline $\begin{array}{c}\text { Self-Suffering } \\
\text { Effacement }\end{array}$ & 0.35 & 0.75 & 0.50 & 1.00 & 0.75 & 0.75 & 0.85 & 0.85 & 0.75 & 0.35 & 0.65 & 0.72 & 0.69 \\
\hline Column Mean & 0.82 & 0.81 & 0.76 & 0.71 & 0.85 & 0.84 & 0.82 & 0.80 & 0.79 & 0.72 & 0.77 & 0.80 & 0.79 \\
\hline
\end{tabular}

Note: "SA" refers to cases charged as sexual assault, "IE" refers to indecent exposure, and "LA" denotes lewd acts. The summary column for "FSA" shows the mean for all crimes charged as a felony and "MIE" refers to a misdemeanor crime. The potential point range was between 1.00 and zero. The actual point range was between 1.00 and 0.15 .

For intake, he wrote, "While buying a pair of boots... I decided to expose myself to you... To see... your reaction ... You were alone; I thought you would get a 'kick out of it'." The victim called her mother and boss; each advised her to call the police. Initially unsure about the conference, she attended, accompanied by biological parents and her step-father. After the conference, the responsible person showed sensitivity to future participants: "Survivor victim should arrive late to avoid contact with responsible person... The impact statement should be sent to the responsible person with sufficient time... to get acquainted with discussion points." During the program, the responsible person was taking blood pressure medicine and underwent therapy for methamphetamine use. Apology letter was scored overall at .79:

Trauma (.85): "It seems like a long time since the day I assaulted you... I never meant to hurt you or frighten you in any way." Learning (.75): "My life has completely changed since that day. I accomplished the necessary retribution and goals that I hope make me a better person to others and myself." Autonomy (.85) "I have tried to do everything in my power to make amends." Responsibility (1.00): "As much as I wish I had not done what I did to you, I have accepted $100 \%$ responsibility for it and tried to do everything in my power to make amends... It was $100 \%$ my fault. Nothing you did had any effect on choices I made." Harm (1.00): "I feel regret, sorrow and shame for pain and damage I caused to you and your family... I understand saying 'sorry' only goes so far."

No language communicated difficulty, except the statement, "I have lost many things that were dear to me..." Oth- erwise, the pertinent language was mild for Ego Neutralization (.75), "I have worked hard to get clean and stay clean," and Suffering (.75) by focusing on his addiction, "I lost many things that were dear to me." For non-specific mention of participation, Gratitude scored lower (.50): "opportunity for a new beginning... valuable lesson... to complete the program."

\section{COMPARING SEXUAL ASSAULT CASES}

We calculated scores for each dimension, and mean ratings by case and crime (Table 1). Mean score across ten dimensions was .79 (range .69 to .91). High scores of 1.00 were assigned to 35 of one-hundred ratings (10 categories $X 10$ responsible persons). Range across cases was tighter than those for dimensions (low at.71, high at.85). The highest were two misdemeanor cases $(.85, .84)$ and lowest cases were one felony (.71) and one misdemeanor (.72). Each dimension and responsible person had at least one score at 1.00. Most had two or more. The narrow range of scores eliminates variation among responsible persons and assault dimensions. Four of the five highest mean dimension scores, for example, ranged from .50 to 1.0. Most the narrow gaps in scores over ten dimensions (.65 to 1.0 ) were misdemeanor cases.

Maximum ratings were common for HarmAcknowledgment (6/10 cases) and Gratitude-Articulation and Egocentric-Neutralization (5/10 each), and less for Space-for-Autonomy and Trauma-Discontinuation (2/10 each). Self-Suffering-Effacement had fewer maximum scores (1/10) and lowest mean score (.69, range 1.00 to .35$)$. Given a high number of maximum ratings, Harm- 
Acknowledgment had a greater mean score (.91, range 1.00 to .75). Each offender, then, presented evidence that he grasped the gravity of actions against the survivor victim, as reflected by scores on Harm-Acknowledgment. Many hesitated in taking full responsibility, as evidenced by the third lowest score for Responsibility-Acceptance (.73), whose scores range widely with notable variability (1.00 to .35$)$ : no more than three at 1.00 and three at .50 or below. In contrast, no score for Harm-Acknowledgement fell below .75 and, as mentioned, six of ten reached 1.00.

Mean ratings between misdemeanor and felony cases diverged for (felony listed first) Space for Autonomy (.90, $.67)$ and Acceptance of Responsibility $(.93, .60)$. Both the categories suggest influence from the immediacy of a personal context to sexual assault. The categories for which misdemeanor apologies were stronger included Avoiding Control $(.71, .93)$, Relationship Extinction $(.59, .88)$ and Trauma Discontinuation $(.53, .85)$. Understandably, most the survivor victims in misdemeanor cases were neither visible nor known to the offender. In short, variation within dimensions across type of assault was notable, although number of cases is too small for statistical comparison.

\section{CONCLUSION}

This analysis explored textual dimensions of apology letters "delivered" to survivor victims of sexual assault in an RJ program that emphasized facilitated conferencing between participants. We highlighted excerpts from responsible person apology letters to illustrate variation in letterbased apologies to survivor victims, and differences between sexual assault types, after twelve months of mutuallydetermined reparation, individual psychotherapy, and regular meetings with program staff and community board. The study contributes to a sparse literature on RJ for sexual assault by qualitatively examining apologies intended for victims harmed by offenders, and for community members who experience the lateral effects from survivor victim harm [see 84]. Textual analysis revealed improved understanding of sexual offense from enrollment to final reflections by responsible persons at the exit meeting, measured by evidential dimensions that were consistent with theoretical goals of offender rehabilitation, especially the difficulty for a show of empathy toward their "victim." Emphasizing qualitative aspects of assault as a trauma-producing, control-seeking, relationship-imposing, ego-centered, harmful act, our assessment of the apology letters highlights potential for growth by responsible persons who were nurtured in a program that was grounded in RJ principles. Compared to diluted allusions to self-responsibility in pre-program documents that were noticeably silent on self-attribution of responsibility, which is not unexpected $[85,86]$, statements reflective of classic sexual assault indicators in the apology letters at the exitmeeting, end-point of the RJ program, attest to its effectiveness to turnaround callous disregard by responsible persons toward their respective survivor victim with a deeper awareness of the harm and suffering caused by the assault perpetrated by each [87].

We identified certain qualitative differences in apology letter content for sexual assault crimes of lesser and greater severity from a statutory perspective (misdemeanor versus felony), although the sample size was too small to generate inferential statistical comparisons. Letters of apology for felony assaults compared to misdemeanor sex crimes differed in Control Avoidance, Relationship Extinction, and Trauma Discontinuation, each a defining assault characteristic. The apologies by felony perpetrators were stronger in Responsibility Acceptance, Space for Survivor Victim Autonomy and Willing to Learn-Change. A difference in mean scores for Responsibility Acceptance between two assault types (dispersion of 0.93 for felony and 0.60 for misdemeanor) reflect the absence of "target visibility" in misdemeanor cases versus definitive visible presence at the time of sexual assault, and, for some felony cases, minimal acquaintance with the victim.

Contributions of this study grounded in qualitative techniques from social science are governed by limitations that include a small sample, based on the low number of referrals from available jurisdictions, and the pre-enrollment attrition. Available material to analyze is limited, owing to short letters from most the responsible persons and a few who declined permission to archive their letter in program files. An additional limitation that constrained the available data was restriction on note-taking at the conference and board meetings. Note-taking other than the observational checklist at the conference was declared off-limits by a policy developed with the prosecutors to avoid a written record that could be subpoenaed as evidence against a responsible person, should his case be pursued in the criminal system for never completing the program.

Our secondary analysis of apology letters relied on triangulation for evaluation. No one on the staff that guided participants through the program or volunteers on the community board that reviewed each case knew their efforts would be evaluated in this fashion. They did not have in mind, as they worked with clients, that the dimensions we adapted from Webster would be the focus of later analysis (his article was published after the program was designed and initiated). In light of this, we find it noteworthy that most rubric scores for responsible persons were notably "clustered in bunches" -- statisticians would say standard deviation was low -which suggests that staff and community volunteers properly oriented participants to "program culture" [see 57], focused on reparative activities that each responsible person was expected to perform. That is, no facet of sexual assault was "left out," as program staff and board members provided professional attention and inter-personal integrity to the needs of each survivor victim and responsible person.

Offenders completing the program apologized in a way that acknowledged benefits from participatory reparation, required therapy and regular meetings with board and staff. The letters demonstrated growth expected with participation [84]. Critical aspect of the texts we examined is what they reveal of restorative justice. Qualitative data would be strengthened by note-taking at the conference and exit meeting. Because staff discouraged responsible persons from apologizing at the conference, when apology occurred, it was delivered voluntarily. What this meant for the participants and how it impacted recovery for survivor victims, could have been examined with observational notes and victimsensitive interviews [65, pp. 11-35, 45-66]. The expression of apology and forgiveness are desired outcomes in sexual assault $[82,88]$, envisioned in program design as possible with 
self-reflection, while responsible persons complete reparative activities, receive therapy and regularly meet with staff and board members, and for survivor victims after psychotherapy and a reasonable passage of time $[48,49,89,90]$. To determine what generates successful program outcomes, all the core elements require scrutiny, especially the designated procedures most effective for facilitated conferencing between participants $[28,3845,91]$ and professionally responsive interactions, while working with survivor victims $[38,48,49$, $56,79-84]$ and responsible persons $[33,67,81,90]$.

Apology was instrumental to program completion, amidst expectations and concerns over returning responsible persons to society as law-abiding citizens, and disadvantages and long-term benefits of RJ in cases of sexual assault. Overall, our analysis found variation between cases of felony and misdemeanor assault, participation that upheld RJ principles and apology letters that demonstrated willingness of responsible persons to learn and grow in ways that lessened classic features of sexual assault through mutually-determined reparation grounded in RJ procedures.

\section{CONFLICT OF INTEREST}

The authors confirm that this article content has no conflicts of interest.

\section{ACKNOWLEDGEMENTS}

We thank the dedicated staff of the Restore Program, the professionals who served as members of the community board, and above all the survivor victims and responsible persons who voluntarily "opted-in" to participate in the program. The authors disclose receipt of the following financial support for the research and/or authorship of this article: A grant awarded to the second author from the National Injury Prevention Center, Centers for Disease Control and Prevention, R49/CCR921709-03, "Prevention Program for Perpetrators."

\section{REFERENCES}

[1] Strang H, Braithwaite J, Eds. Restorative justice and civil society. Cambridge, MA: Cambridge University Press 2001.

[2] McAlinden A-M. The use of 'shame' with sexual offenders. Br J Criminol 2005; 45(3): 373-94.

[3] Braithwaite J. Restorative justice and responsive regulation. New York, NY: Oxford University Press 2002

[4] Hadley ML. The spiritual roots of restorative justice. Albany, NY: State University of New York Press 2001

[5] Sawatsky J. The ethic of traditional communities and the spirit of healing justice: studies from Hollow Water, the Iona Community, and Plum Village. London, UK: Jessica Kingsley Publishers 2009.

[6] Braithwaite J. Crime, shame and reintegration. Cambridge, MA: Cambridge University Press 1989.

[7] Daly K, Curtis-Fawley S. Victim advocacy groups and the idea of restorative justice. Violence Against Women 2005; 11(5): 603-38.

[8] Daly K, Stubbs J. Feminist engagement with restorative justice. Theor Criminol 2006; 10(1): 9-28.

[9] Van Wormer K. Restorative justice as social justice for victims of gendered violence: a standpoint feminist perspective. Soc Work 2009; 54(2): 107-16.

[10] Koss MP. Blame, shame, and community: justice responses to violence against women. Am Psychol 2000; 55(11): 1332-43.

[11] Koss MP. Feminism, restorative justice and crimes against women. In: Ptacek J, Ed. Restorative justice and crimes against women. New York, NY: Oxford University Press 2010; pp. 218-38.

[12] Ptacek J. Resisting co-optation: three feminist challenges to antiviolence work. In: Ptacek J, Ed. Restorative justice and violence against women. New York, NY: Oxford University Press 2010; pp. 5-36.

[13] Bazemore G, Umbreit MS. A comparison of four restorative conferencing models (Bulletin \#NCJ-184738). Washington, DC: Office of Juvenile Justice and Delinquency Prevention, US Department of Justice 2001

[14] Umbreit MS, Vos B, Coates RB, Lightfoot E. Restorative justice in the twenty-first century: a social movement full of opportunities and pitfalls. Marquette Law Rev 2006; 89: 251-304.

[15] Hopkins CQ, Koss MP, Bachar KJ. Applying restorative conference to ongoing intimate violence: problems and possibilities. St Louis Univ Public Law Rev 2004; 23: 289-312.

[16] Cossins A. Restorative justice and child sex offences: the theory and the practice. Br J Criminol 2008; 48(3): 359-78.

[17] Daly K. Setting the record straight and a call for radical change. $\mathrm{Br}$ J Criminol 2008; 48(4): 557-66.

[18] Nancarrow H. Restorative justice for domestic and family violence: hopes and fears of indigenous and non-indigenous Australian women. In: Ptacek J, Ed. Restorative Justice and Violence Against Women. New York, NY: Oxford University Press 2010; pp. 123149.

[19] Goel R. Aboriginal women and political pursuit in Canadian sentencing circles: at cross roads or cross purposes? In: Ptacek J, Ed. Restorative justice and violence against women. New York, NY: Oxford University Press 2010; pp. 60-78.

[20] Wilson RJ, Prinzo M. Circles of support: a restorative justice initiative. J Psychol Human Sex 2002; 13(3/4): 59-77.

[21] Dylan A. Talking circles: a traditional form of group work. In: Dylan A, Ed. Social work with groups: social justice through personal, community and societal change. New York, NY: Haworth Press 2003; pp. 119-33.

[22] Maxwell G, Morris A. What is the place of shame in restorative justice? In: Zehr H, Toews B, Eds. Critical issues in restorative justice. Monsey, NY: Criminal Justice Press 2004; pp. 133-42.

[23] Szmania SJ. Mediators' communication in victim offender mediation/dialogue involving crimes of severe violence: an analysis of opening statements. Conflict Resolut Q 2006; 24(1): 111-27.

[24] Pranis K, Stuart B, Wedge M. Peacemaking circles: from crime to community. St. Paul, MN: Living Justice Press 2003.

[25] Kenney JS, Clairmont D. Interactional dynamics of restorative justice sessions. J Contemp Ethnogr 2009; 38(3): 279-307.

[26] Bowen H, Boyack J, Marshall C. How does restorative justice ensure good practice? In: Zehr H, Toews B, Eds. Critical issues in restorative justice. Monsey, NY: Criminal Justice Press 2004; pp. 265-76.

[27] Daly K. Restorative justice and sexual assault: an archival study of court and conference cases. Br J Criminol 2006; 46: 334-56.

[28] Koss MP. Restoring rape survivors: justice, advocacy, and a call to action. Ann N Y Acad Sci 2006; 40: 1-30.

[29] Koss MP, Achilles M. Restorative justice responses to sexual assault [Online]. Applied Research Forum of the National Online Resource Center on Violence Against Women [cited 2008]. Available from: > http://new.vawnet.org/Assoc_Files_VAWnet/AR_RestorativeJustice.pdf

[30] Orth U, Maercker A. Do trials of perpetrators re-traumatize crime victims? J Interpers Violence 2004; 19(2): 212-27.

[31] Larcombe W. Sex offender risk assessment: the need to place recidivism research in the context of attrition in the criminal justice system. Violence Against Women 2012; 18(4): 482-501.

[32] Spohn C, Tellis K. The criminal justice system's response to sexual violence. Violence Against Women 2012; 18(2): 169-92.

[33] Cesaroni C. Releasing sex offenders into the community through 'circles of support': a means of reintegrating the 'worst of the worst'. J Offender Rehabil 2001; 34(2): 85-98.

[34] Sherman LW, Strang H, Angel C, et al. Effects of face-to-face restorative justice on victims of crimes in four randomized trials. $\mathrm{J}$ Exp Criminol 2005; 1: 367-95.

[35] Wilson RJ, Huculak B, McWhinnie A. Restorative justice innovations in Canada. Behav Sci Law 2002; 20: 363-80.

[36] Herman JL. Justice from the victim's perspective. Violence Against Women 2005; 11(5): 571-602.

[37] Auburn T. Narrative reflexivity as a repair device for discounting 'cognitive distortions' in sex offender treatment. Discourse Soc 2005; 16(5): 697-718.

[38] Daly K, Curtis-Fawley S. Restorative justice for victims of sexual assault. In: Heimer K, Kruttschnitt C, Eds. Gender and crime: pat- 
terns of victimization and offending. New York, NY: New York University Press 2006; pp. 230-65.

[39] Campbell R. Rape survivor's experiences with the legal and medical systems: do rape victim advocates make a difference? Violence Against Women 2006; 12(1): 30-45.

[40] Stubbs J. Relations of domination and subordination: challenges for restorative justice in responding to domestic violence. Univ New South Wales Law J 2010; 33: 970-86.

[41] Buschman J, Wilcox D, Spreen M, Marshall B, Bogaerts S. Victim ranking among sex offenders. J Sex Aggress 2008; 14(1): 45-52.

[42] Marshall WL, Marshall LE, Serran GA, O’Brien MD. Self-esteem, shame, cognitive distortions and empathy in sexual offenders: their integration and treatment implications. Psychol Crime Law 2009; 15(2-3): 217-34

[43] Varker T, Devilly GJ, Ward T, Beech AR. Empathy and adolescent sexual offenders: a review of the literature. Aggress Violent Behav 2008; 13(4): 251-60

[44] Cargo M, Mercer SL. The value and challenges of participatory research: strengthening its practice. Ann Rev Public Health 2008; 29: 325-50.

[45] Sullivan D, Tift L. Restorative justice: healing the foundations of our lives. Monsey, NY: Willow Tree Press 2001.

[46] Bennett C. The apology ritual: a philosophical theory of punishment. Cambridge, MA: Cambridge University Press 2008.

[47] Zehr H, Toews B, Eds. Critical issues in restorative justice. Monsey, NY: Criminal Justice Press 2004.

[48] Koss MP, Bachar KJ, Hopkins CQ, Carlson C. Expanding a community's justice response to sex crimes through advocacy, prosecutorial, and public health collaboration: introducing the RESTORE Program. J Interpers Violence 2004; 19(12): 1435-63.

[49] Koss MP. Restorative justice for acquaintance rape and misdemeanor sex crimes. In: Koss MP, Ed. Restorative justice and violence against women. New York, NY: Oxford University Press 2010b; pp. 218-38.

[50] Rozee PD, Koss MP. Rape: a century of resistance. Psychol Women Q 2001; 25: 295-311.

[51] Webster SD. Assessing victim empathy in sexual offenders using the victim letter task. Sex Abuse 2002; 14(4): 281-300.

[52] Bandura A. Self-efficacy: the exercise of control. New York, NY: Henry Holt and Company 1997.

[53] Bandura A. Self-efficacy mechanism in human agency. Am Psychol 1982; 37(2): 122-47.

[54] Daly K, Bonhours B. Rape and attrition in the legal process: a comparative analysis of five countries. Crime Justice 2010; 39: 565-650.

[55] Lonsway KA, Archambault J. The 'justice gap' for sexual assault cases: future directions for research and reform. Violence Against Women 2012; 18(2): 145-68.

[56] Mulla S. Facing victims: forensics, visual technologies, and sexual assault examination. Med Anthropol 2011; 30(3): 271-94.

[57] Becker HS. Tricks of the trade: how to think about your research while you're doing it. Chicago, IL: University of Chicago Press 1998.

[58] Maxwell J. Qualitative research design: an interpretative approach. Thousand Oaks, CA: Sage 2004.

[59] Bletzer KV, Koss MP. From parallel to intersecting narratives in cases of sexual assault. Qual Health Res 2011;22(3): 291-303.

[60] Cornish F. The roles of (written) text and anaphor-type distribution in the construction of discourse. Text 2003; 23(1): 1-26.

[61] Dixon P, Bortolussi M. Text is not communication: a challenge to a common assumption. Discourse Process 2001; 31(1): 1-25.

[62] Small ML. 'How many cases do I need?' on science and the logic of case selection in field-based research. Ethnography 2009; 10(1): 5-38.

[63] Tavory I, Timmermans S. Two cases of ethnography: grounded theory and the extended case method. Ethnography 2009; 10(3): 243-63.

[64] Ryan GW, Bernard HR. Techniques to identify themes. Field Methods 2003; 15(1): 85-109.

[65] LeCompte MD, Schensul JJ. Analyzing and interpreting ethnographic data. In: Schensul JJ, Le Compte MD, General Eds. Eth- nographer's Toolkit. Walnut Creek, CA: AltaMira Press 1999; vol. 5: pp. 1-225.

[66] Webster SD, Beech AR. The nature of sexual offenders' affective empathy: a grounded theory analysis. Sex Abuse 2000; 12(4): 24961.

[67] Roseman CP, Ritchie M, Laux JM. A restorative justice approach to empathy development in sex offenders: an exploratory study. J Addict Offender Couns 2009; 29: 96-109.

[68] Krishnan K, Feller MJ, Orkin M. Goal setting, planning, and prioritizing. In: Meltzer L, Ed. Promoting executive function in the classroom: what works for special-needs learners. New York, NY: Guilford Press 2010; pp. 57-85.

[69] Kim H-JJ, Millis K. The influence of sourcing and relatedness on event integration. Discourse Process 2006; 41(1): 51-65.

[70] Hall JM. Narrative methods in a study of trauma recovery. Qual Health Res 2011;21(1): 3-13.

[71] Hamilton JA. On the ethics of unusable data. In: Faubion JD, Marcus GE, Eds. Fieldwork is not what it used to be. Ithaca, NY: Cornell University Press 2009; pp. 73-88.

[72] Holmes J. Apologies in New Zealand English. Lang Soc 1990; 19(2): 155-99.

[73] Wouk F. The language of apologizing in Lombok, Indonesia. J Pragmat 2006; 38: 1457-86.

[74] Park H, Guan X. Culture, positive and negative face threats, and apology intentions. J Lang Soc Psychol 2009b; 28(3): 244-62.

[75] Nureddeen FA. Cross-cultural pragmatics: apology strategies in Sudanese Arabic. J Pragmat 2008; 40: 279-306.

[76] Park HS, Guan X. Cross-cultural comparison of verbal and nonverbal strategies of apologizing. J Int Intercult Commun 2009a; 2(1): 66-87.

[77] Bataineh RF, Bataineh RF. A cross-cultural comparison of apologies by native speakers of American English and Jordanian Arabic. J Pragmat 2008; 40: 792-821.

[78] Petrucci CJ. Apology in the criminal justice setting: evidence for including apology as an additional component in the legal system. Behav Sci Law 2002; 20: 337-62.

[79] Armour MP, Umbreit MS. Victim forgiveness in restorative justice dialogue. Vict Offender 2006; 1: 123-40.

[80] Sells JN, Hargrave TN. Forgiveness: a review of the theoretical and empirical literature. J Fam Ther 1998; 20(1): 21-36.

[81] Fisher ML, Exline JJ. Self-forgiveness versus excusing: the roles of remorse, effort and acceptance of responsibility. Self Identity 2006; 5: 127-46.

[82] Hareli S, Eisikovits Z. The role of communicating social emotions accompanying apologies in forgiveness. Motiv Emot 2006; 30: 189-97.

[83] Walton E. Therapeutic forgiveness: developing a model for empowering victims of sexual abuse. Clin Soc Work J 2005; 33(2): 193-207.

[84] Wies JR, Coy K. Measuring violence: vicarious trauma among sexual assault nurse examiners. Hum Organ 2013; 72(1): 23-30

[85] Kampf Z. Public (non-)apologies: the discourse of minimizing responsibility. J Pragmat 2009; 41: 2257-70.

[86] Coates L, Wade A. Telling it like it isn't: obscuring perpetrator responsibility for violence crime. Discourse Soc 2004; 15(5): 499-526.

[87] Achilles M. Can restorative justice live up to its promise to victims? In: Zehr H, Toews B, Eds. Critical Issues in Restorative Justice. Monsey, NY: Criminal Justice Press 2004; pp. 65-73.

[88] Van Stokkom B. Moral emotions in restorative conferences: managing shame, designing empathy. Theor Criminol 2002; 6: 339-60.

[89] Wozniak DF, Allen KN. Ritual and performance in domestic violence healing: from survivor to thriver through rites of passage. Cult Med Psychiatry 2012; 36(1): 80-101.

[90] Ward T, Langlands R. Repairing the rupture: restorative justice and the rehabilitation of offenders. Aggress Violent Behav 2009; 14 205-14.

[91] Choi JJ, Sevenson M. 'What! what kind of apology is this?': the nature of apology in victim offender mediation. Child Youth Sery Rev 2009; 31(7): 813-20. 